\title{
Effect of ultrasound on human umbilical cord peri-vascular cells
}

\author{
Taghreed A. Aldosary ${ }^{1}$, Hasan Uludag ${ }^{2}$, Michael R. Doschak ${ }^{3}$, Tarek El-Bialy ${ }^{4}$ \\ 1. National Guard Health Affairs, Community and Preventive Medicine, Jeddah, Saudi Arabia. 2. University of Alberta, \\ Department of Chemical and Material Engineering, Edmonton, Canada. 3. University of Alberta, Faculty of Pharmacy \& \\ Pharmaceutical Sciences, Edmonton, Canada. 4. University of Alberta, School of Dentistry, Faculty of Medicine $\&$ Dentistry, \\ Edmonton, Canada.
}

Correspondence: Tarek El-Bialy, Associate Professor. Address: Orthodontics and Biomedical Engineering, 7-020D Katz Group Centre for Pharmacy and Health Research, University of Alberta, Edmonton T6G 2E1, Canada.

Email: telbialy@ualberta.ca

Received: June 16, 2015

Accepted: August 6, 2015

Online Published: August 14, 2015

DOI : $10.5430 /$ jbei.v1n1p70

URL: http://dx.doi.org/10.5430/jbei.v1n1p70

\section{Abstract}

Background: Tissue engineering involves using different types of stem cells. One of the roadblocks in tissue engineering is the scant supply of stem cells. The potential use of human umbilical cord peri-vascular Cells (HUCPVCs) has recently been considered as an important cell source for tissue engineering applications. The objective of this study was to explore the effect of low intensity pulsed ultrasound (LIPUS) on HUCPVCs.

Materials and methods: HUCPVCs were divided into two groups: treatment group which received $30 \mathrm{~mW} / \mathrm{cm}^{2}$ LIPUS for 10 minutes $(1,7$, and 14 days) and control group which received sham treatment. The study groups were evaluated for cell count, alkaline phosphatase (ALP) activity, DNA-content, gene expression, and immunophenotype.

Results: There was no significant differences in cell count, ALP, DNA-content, and CD-90 between LIPUS and control groups. A significantly higher expression of OSP and PCNA was observed on day 14 in LIPUS treatment group.

Conclusion: LIPUS application for 10 minutes per day for 14 days enhanced OSP and PCNA expression without significant increase in cell count of HUCPVCs. Future research may aim at exploring different LIPUS applications (different time and frequency) to optimize HUCPVCs proliferation.

\section{Key words}

Low intensity pulsed ultrasound, Stem cells, Human umbilical cord peri-vascular cells

\section{Introduction}

An adequate source of mesenchymal progenitor cells (MPCs) is increasingly needed for cell therapy and tissue engineering. The interest in MPCs has recently increased as a tool for therapeutic applications because of their unique characteristics, including the relative ease of culture and the high potential for their expansion in vitro ${ }^{[1]}$. Bone marrow has been historically the primary source of MPCs. However, the harvest of cells from bone marrow involves an invasive procedure that may predispose the donor site to risk of infection and morbidity ${ }^{[2-5]}$. Another shortcoming is that the proliferation and differentiation capacity of bone marrow MPCs decreases with age ${ }^{[2]}$. 
Umbilical cord (UC) cells have been investigated and it has been shown that cells from perivascular (PV), Wharton's jelly (WJ) contain significantly lesser CD40+ non-stem cell contaminants (26\%-27\%) compared to cells from other UC compartments ${ }^{[6]}$. The same authors showed that cells isolated from (WJ) can offer the best clinical utility ${ }^{[6]}$. One potential solution to this problem is the possible utilization of human umbilical cord peri-vascular cells (HUCPVCs), which comprise a cell population capable of exhibiting a functional mesenchymal phenotype ${ }^{[2-5]}$. Undifferentiated stromal mesenchymal cells from umbilical cord are immunologically suppressed and therefore may be considered for cell transplantation ${ }^{[6-9]}$. Multiple studies have shown that HUCPVCs are negative for the endothelial/hematopoietic cell markers CD34, CD45, and MHCII, but stained positively for MSC markers, namely CD90 and MHCI ${ }^{[3,5,10-12]}$. These cells demonstrated the possibility to differentiate into osteogenic cells after 3 weeks, as well as into multiple mesenchymal lineages ${ }^{[3,11-13]}$. It has been reported that HUCPVCs can be differentiated into osteocytes after 2 weeks ${ }^{[12]}$. The HUCPVCs continued to test negative for MHCII and CD31, but positive for MHCI, similar to bone marrow MSCs ${ }^{[13]}$. Furthermore, several in vitro studies revealed that HUCPVCs were negative to CD34, CD45, CD31, and MHCII, but persistently stained positive for CD90 ${ }^{[14-18]}$. These findings eliminated the possibility of endothelial or hematopoietic contamination in this cell population and have provided a pure MSC progenitor precursor for therapeutic purposes.

Therapeutic application of ultrasound has proven to facilitate healing of bone fractures with special significance of the low-intensity pulsed ultrasound (LIPUS) ${ }^{[19]}$. The stimulatory effect of LIPUS application was related to an increase in the integration of calcium ions into osseous and soft tissues ${ }^{[20]}$. LIPUS also appeared to stimulate the expression of genes that mediate the healing process, including the proteoglycan aggrecan and IGF (Insulin-like Growth Factor) expression ${ }^{[20]}$. A previous study has shown that a single 50-second LIPUS application to human umbilical cord-derived cells increased cell proliferation especially in the first few days (3-5 days) ${ }^{[21]}$. However, the applied LIPUS pulse repetition frequency $(40 \mathrm{KHz})$ was too high compared to the clinically used LIPUS pulse repetition frequency $(1 \mathrm{KHz})$. Recently, it has been shown that LIPUS enhances bone marrow and adipose stem cell osteogenic differentiation, however the technique is still yet to be optimized ${ }^{[22]}$. The aim of this study was to explore whether the LIPUS has a stimulatory effect on HUCPVCs proliferation while maintaining their phenotypic characteristics. Other types of ultrasound (ultrasound-targeted microbubble destruction (UTMD) has been used recently to mobilize bone marrow stem cells for tissue repair ${ }^{[23]}$. The ultrasound parameters used in their study (US frequency $=1 \mathrm{MHz}$; duty cycle $=10 \%$; peak negative pressure $=0.6 \mathrm{~W} / \mathrm{cm}^{2}$ $(0.35 \mathrm{MPa})$; total irradiation time $=30 \mathrm{~s}$; dosage of $\left.\mathrm{MBs}=10^{6} / \mathrm{mL}\right)$ however were different from those that have been used for therapeutic application.

\section{Material and methods}

\subsection{Cell culture}

Approval was obtained from Health Research Ethics Board, University of Alberta, Edmonton, Canada (approval number 6431). Umbilical cords were obtained, following informed written consent, from patients undergoing full-term caesarean sections. HUCPVCs were isolated according to methods described before ${ }^{[5]}$. Cells at passage 1 were thawed and were seeded into three T-75 $\mathrm{cm}^{2}$ tissue culture flasks (Sigma Aldrich, Oakville, ON, Canada) containing Dulbecco's modified Eagle's medium with low glucose (DMEM-LG) (GIBCO, Invitrogen, Burlington, ON, Canada) supplemented with 15\% Fetal Bovine Serum (FBS) (GIBCO, Invitrogen, Burlington, ON, Canada), and 1\% Antibiotic-Antimycotic (Sigma Aldrich, Oakville, ON, Canada) at initial cell density of $3.6 \times 10^{6} / \mathrm{ml}$. Cells were incubated at $37^{\circ} \mathrm{C}$ and $5 \% \mathrm{CO}_{2}$ then expanded for 10 days till $\mathrm{P} 4$ and media was changed every 2-3 days. When the cell confluence reached $80 \%\left(4.2 \times 10^{6} / \mathrm{ml}\right)$, they were harvested and trypsinized using $0.25 \%$ Trypsin (GIBCO, Invitrogen), collected in $50 \mathrm{ml}$ tubes, centrifuged, then seeded in nine 6 well plates (Sigma Aldrich, Oakville, ON, Canada) at $\left(2 \times 10^{4}\right) / \mathrm{ml}^{[24,25]} .27$ wells per group were treated for $10 \mathrm{~min} /$ day by 4 ultrasound devices "Exogen LIPUS transducers, Smith and Nephew, Mississauga, ON, Canada" with 4 transducers placed immediately below the wells and coupled to the well bases with standard ultrasound coupling gel ${ }^{\text {[24] }}$. The ultrasound transducers produce $1.5 \mathrm{MHz}$ ultrasound waves comprising $200 \mu$ s bursts at a pulse repetition frequency of $1 \mathrm{KHz}$ and output intensity of $30 \mathrm{~mW} / \mathrm{cm}^{2}$. Transducers were calibrated before and after applications for consistency of Published by Sciedu Press 
electrical waveforms (1 KHz modulation, 200 microseconds pulse duration, and $1.5 \mathrm{MHz}$ pulse frequency) ${ }^{[22]}$ using TDS1012C-EDU digital oscilloscope (Tektronix, Canada), and calibrated for ultrasound intensity of $30 \mathrm{~mW} / \mathrm{cm}^{2}$ using an ultrasound power-meter (model UPM-DT-1AV from Ohmic Instruments, Easton, MD, USA). The calibrations at the beginning and at the end of the experiments confirmed that the ultrasound devices provided stable ultrasound power output and maintained the desired parameters during the experiment. Temperature was maintained at $37^{\circ} \mathrm{C}$ within the incubator while LIPUS was applied. LIPUS was applied to cell culture plates $(n=27)$ for 10 minutes per day for 1 day, 7 days and 14 days. The other control wells $(\mathrm{n}=27)$ were treated using the same transducers without turning the machines on (sham control). Each group was evaluated at each time point (1, 7 and 14 days).

\subsection{Cell count}

Cells were washed using PBS (GIBCO, Invitrogen, Burlington, ON, Canada) then trypsinized. Cells and medium were collected in $15 \mathrm{ml}$ tubes for spinning $(6 \mathrm{~min} / 600 \mathrm{rpm})$. The supernatant was vacuumed away. Cells were counted using Beckman Coulter Machine (Beckman coulter Canada Inc., Burlington, ON, Canada).

\subsubsection{Alkaline phosphatase activity assay}

HUCPVCs ALP activity was determined by the colorimetric assay at the indicated time points. ALP is a biochemical marker for cell differentiation of osteogenic lineage ${ }^{[21,22,24,26,27]}$. Cells were washed with PBS and lysed with $2 \mathrm{~mL}$ of ALP buffer per well (0.5 M 2-amino-2-methyl-1-propanol and 0.1\% Triton- X-100, pH 10.5). Two hours later, after lysis, $1 \mathrm{~mL}$ of lysed cells was used for DNA quantification assay. Phosphatase substrate (p-nitrophenyl phosphate) (Sigma, Oakville, ON, Canada) was added to ALP buffer in $1 \mathrm{mg} / \mathrm{ml} \mathrm{(1:1)} \mathrm{ratio.} 100 \mu 1$ of lysed cells and $100 \mu 1$ of substrate mixture were loaded to each well into 96 well plate of a final concentration of $1 \mathrm{mg} / \mathrm{mL}$. The changes in optical density (absorbance, $405 \mathrm{~nm}$ ) were determined in a multiwell plate reader (ELX800 Universal Microplate Reader, Bio-Tek Instruments, Inc. in Winooski, Vermont, USA.) at periodic intervals 5, 10, 15, 30 minutes.

\subsubsection{Cell proliferation \& DNA quantification assay}

Lysed cell solution $(1 \mathrm{~mL})$ was used to measure the amount of DNA with the CyQUANT Cell proliferation kit (Molecular Probe, Invitrogen, Burlington, ON, Canada). The CyQUANT cell proliferation kit assay relies on the measurement of DNA quantity through binding with fluorescent dye (Molecular Probe, Invitrogen, Burlington, ON, Canada). The extent of proliferation is determined by comparing cell's DNA content for treated samples with untreated controls. The CyQUANT kit protocol requires cell binding with the dye solution, incubation for 30-60 minutes, and then measurement of fluorescence in a microplate reader (Fluoroskan Ascent, Thermo Labsystems, Finland). The assay is designed to produce a linear analytical response in a 96-well microplate (Molecular Probe, Invitrogen, Burlington, ON, Canada). DNA standard provided with the CyQUANT kit was utilized to determine the DNA concentrations in each group of cells. According to the manufacturer's instructions, DNA was quantified using a fluorescence plate reader (excitation at $480 \mathrm{~nm}$; emission at $527 \mathrm{~nm})$.

\subsubsection{I mmunophenotyping using flow-cytometry analysis}

Further characterization of expanded HUCPVCs at passage 4 using cell surface antigen phenotyping was performed on days 1, 7 and 14. The following cell-surface epitopes were labeled with anti-human antibodies: CD31(PECAM-1) fluorescein isothiocyanate (FITC, BD Biosciences, Mississauga, ON, Canada), CD34-R-phycoerythrin (R-PE, BD Biosciences, Mississauga, ON, Canada), CD45-phycoerythrin (PE, BD Biosciences, Mississauga, ON, Canada), CD90 (Thy1) R-phycoerythrin (R-PE, BD Bioscience, Mississauga, ON, Canada), MHC I (HLA-A,B,C) R-phycoerythrin (R-PE, BD Bioscience, Mississauga, ON, Canada), and MHC II (HLA-DR) fluorescein isothiocyanate (FITC, BD Biosciences, Mississauga, ON, Canada) (Becton Dickinson; Beckman Coulter, Mississauga, ON, Canada), FITC-conjugated sotypemouse IgGa1 and PE-conjugated Isotype-mouse IgGk1 served as secondary antibodies (control antibodies). 10,000 labeled cells were acquired and analyzed using a FACScan flow cytometer running CellQuest software (Becton Dickinson, Mississauga, ON, Canada). Details about these markers are described in Table 1. HUCPVCs were suspended and prepared using standard direct staining protocols ${ }^{[28-30]}$. 
Table 1. Description of cell surface markers

\begin{tabular}{ll}
\hline Markers & Description \\
\hline CD90 & Mesenchymal stromal cell marker \\
CD31 & endothelial cell marker \\
CD34 & hematopoietic cells and vascular endothelium marker \\
CD45 & differentiated hematopoietic cell marker \\
MHC I & Recognized during graft rejection and found on all nucleated cells \\
MHCII & a marker for B-lymphocytes, macrophages and dendritic cells \\
\hline
\end{tabular}

\subsubsection{Quantitative real time-PCR analysis (Q-PCR)}

RNA was isolated and cDNA was synthesized; total RNA was extracted from each triplicate group of both LIPUS treated and sham groups using the RNeasy Mini Kit (Qiagen, Mississauga, ON, Canada). RNA samples were quantified fluorometrically at $260 \mathrm{~nm}$ using SYBRgreen (Molecular Probes, OR, USA), as recommended by the manufacturer. Single stranded DNA (cDNA) was synthesized from $1 \mu \mathrm{g}$ of total RNA using the Omniscript Reverse Transcription kit (Qiagen, Mississauga, ON, Canada). Primers for real-time PCR were designed with Primer Express 2.0 software from Applied Biosystems (AB, Foster City, CA, USA). RT-PCR reactions were performed using TaqMan ${ }^{\circledR}$ Gene Expression Assays (Applied Biosystems AB, Foster City, CA, USA) and TaqMan ${ }^{\circledR G e n e}$ Expression Assays protocol (Applied Biosystems AB, Foster City, CA, USA). The TaqMan ${ }^{B} M G B$ probes and primers were premixed to a concentration of $18 \mu \mathrm{M}$ for each primer and $5 \mu \mathrm{M}$ for the probe. Amplifications were carried out in a final reaction volume of $10 \mu 1$. Gene's assays ID and gene's symbols were explained in Table 2; the reaction mixtures were aliquoted into 96-well ABI reaction plate. The plates was then placed in an ABI Prism 7500 fast system V 1.4.0 Applied Bio-system Q-PCR machine under the following conditions: stage 1 consisted of $95^{\circ} \mathrm{C}$ for $10 \mathrm{~min}$; stage 2 consisted of 40 cycles of $95^{\circ} \mathrm{C}$ for $15 \mathrm{~s}$, followed by $60^{\circ} \mathrm{C}$ for $1 \mathrm{~min}$. The Q-PCR data were analyzed with SDS 7500 Fast system V.2.01 software (AB, Foster City, CA, USA).

Table 2. Genes used for Q-PCR analysis

\begin{tabular}{lll}
\hline Gene Name & Gene Symbol & Assay ID \\
\hline $\begin{array}{l}\text { Endogenous Control Human GAPDH (Glyceraldehyde 3-phosphate } \\
\text { dehydrogenase) }\end{array}$ & GAPDH & 4333764F \\
Osteocalcin (OCN) & BGLAP & Hs00609452_g1 \\
Osteopontin (OPN) & SPP1 & Hs00959009_m1 \\
Proliferating cell nuclear antigen (PCNA) & PCNA & Hs99999177_g1 \\
Nucleostemin (NST) & GNL3 & Hs00205071_m1 \\
\hline
\end{tabular}

\subsection{Statistical analysis}

Data are presented as mean \pm standard deviation. MANOVA was used to compare the expansion capacities of treated (LIPUS) group and control (sham) group. A two-way ANOVA was used to analyze the flow-cytometry data and Q-PCR data. Differences were considered significant at $(P<.05)$. The SPSS software package (version 16.0; SPSS Inc., Chicago, IL, USA) was used for the statistical tests.

\section{Results}

The HUCPVCs were observed at day 1, 7 and 14 after the application of LIPUS. There was no significant difference in cell count (see Figure 1) or DNA content between the LIPUS-treated and control groups (see Figure 2). The ALP activity (normalized with DNA) was increased at day 1 in LIPUS-treated group but it was lower at day 7 as compared to 
sham-treated group. ALP/DNA activity increased but not statistically significant at day 14 in LIPUS-treated group (see Figure 2).

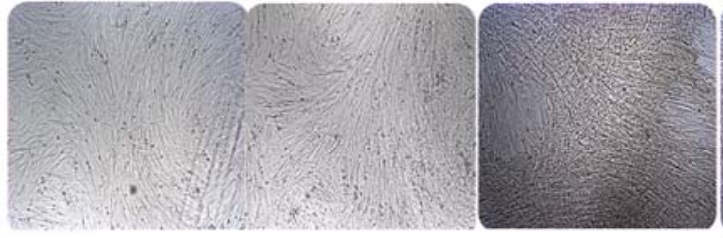

A
B

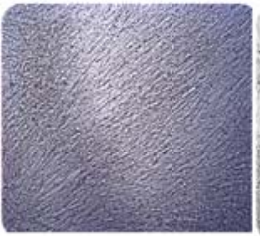

D

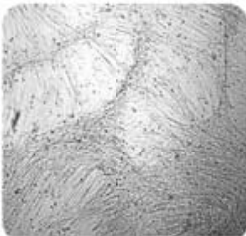

E

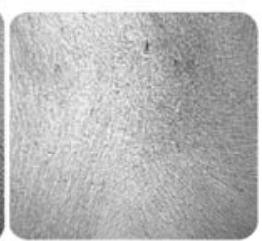

$\mathbf{F}$

Figure 1. Cellular morphology images of HUCPVCs. Control and treated with LIPUS $10 \mathrm{~min} /$ day on days 1 (A, B), $7(\mathrm{C}, \mathrm{D})$, and $14(\mathrm{E}, \mathrm{F})$ respectively in basic media

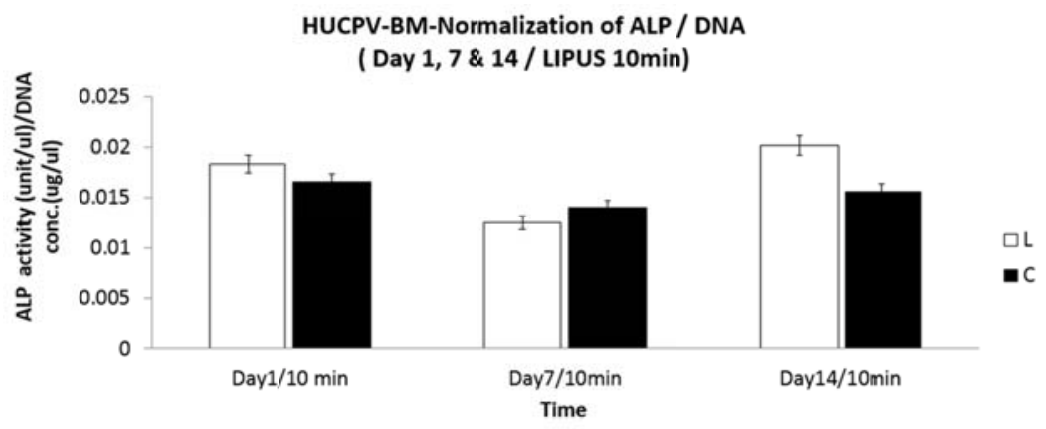

Figure 2. HUCPV-normalization of ALP/DNA results after application of LIPUS $10 \mathrm{~min} /$ day (days 1, 7, and 14) in basic media, $\mathrm{L}=$ LIPUS, $\mathrm{C}=$ control, HUCPV= Human Umbilical cord Perivascular. Cells were at P4 ( $\mathrm{n}=12)$, data represent quantification from 3 biological replicates, error has indicate standard deviation

Immunophenotyping analysis was used to analyze cell surface markers on HUCPVCs at passage 4. HUCPVCs were negative for CD31 and MHCII. The HUCPVCs were also negative for CD34 and CD45. Conversely, they were strongly positive for CD90 and moderately positive for MHCI. LIPUS-treated HUCPVCs expressed a high level of CD90 at day 14 compared with Sham treated group (see Table 3, Figure 3). There was no statistically significant difference between LIPUS and control groups with regard to expression of any of the cell markers (see Table 3 ).

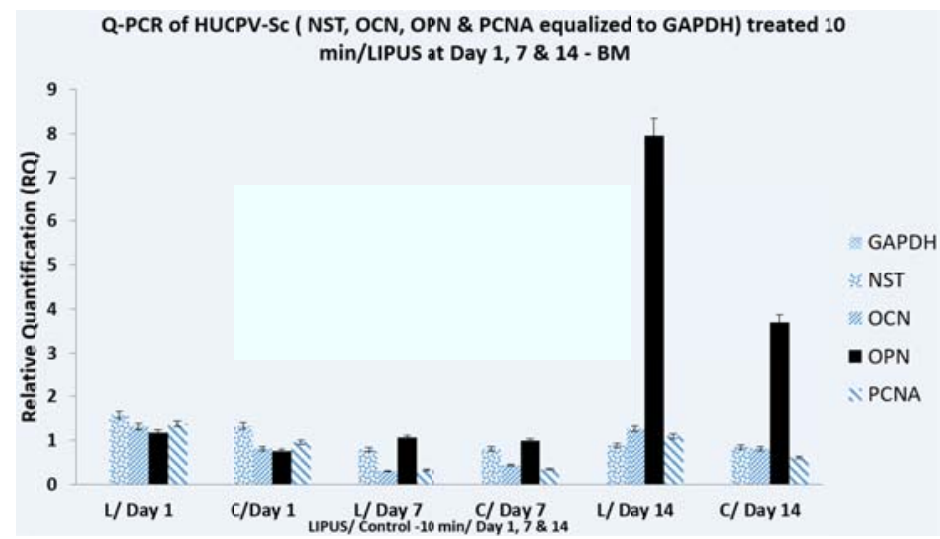

Figure 3. Flow-cytometry of HUCPV-C (isotype IgG, CD31, CD90, CD34, CD45, MHCI, and MHCII) treated with LIPUS $10 \mathrm{~min} /$ day on days 1, 7, and 14 in basic media; differences between LIPUS (L) and control (C). Cells were at P4 $(\mathrm{n}=27)$, data represent quantification from 3 biological replicates, error has indicate standard deviation 
Table 3. Comparison of cell surface markers expression of flow-cytometry results of HUCPV-SC (isotype IgG, CD31, CD90, CD34, CD45, MHCI, and MHCII) treated with LIPUS $10 \mathrm{~min} /$ day on days 1, 7, and 14: difference between LIPUS $(\mathrm{L})$ and control $(\mathrm{C})$ in basic media. The results expressed as Mean $\pm \mathrm{SD}$.

\begin{tabular}{|c|c|c|c|c|c|c|c|c|c|c|}
\hline \multirow{2}{*}{$\begin{array}{l}\text { Markers } \\
\text { /BM }\end{array}$} & \multicolumn{3}{|l|}{ Day 1} & \multicolumn{3}{|l|}{ Day 7} & \multicolumn{4}{|l|}{ Day 14} \\
\hline & $\mathbf{L}$ & C & $P$-Value & $\mathbf{L}$ & C & $P$-Value & $\mathbf{L}$ & C & & $P$-Value \\
\hline $\begin{array}{l}\text { Isotype } \\
\text { IgG }\end{array}$ & $\begin{array}{l}3 \pm \\
0.9\end{array}$ & $\begin{array}{l}8.3 \pm \\
4\end{array}$ & .2 & $\begin{array}{l}27.3 \pm \\
9.7\end{array}$ & $\begin{array}{l}25.4 \pm \\
8.1\end{array}$ & .8 & $\begin{array}{l}9.9 \pm \\
2.5\end{array}$ & $\begin{array}{l}6.5 \pm \\
2.9\end{array}$ & & .8 \\
\hline CD31 & $\begin{array}{l}16.3 \pm \\
8.8\end{array}$ & $\begin{array}{l}19.8 \pm \\
13.5\end{array}$ & .8 & $\begin{array}{l}41.6 \pm \\
12.5\end{array}$ & $\begin{array}{l}38.9 \pm \\
10.9\end{array}$ & .2 & $\begin{array}{l}13.7 \pm \\
1.7\end{array}$ & $\begin{array}{l}8.9 \pm \\
1.3\end{array}$ & & .2 \\
\hline CD90 & $\begin{array}{l}2211.9 \pm \\
1644.4\end{array}$ & $\begin{array}{l}3204 \pm \\
689.6\end{array}$ & .3 & $\begin{array}{l}3896.9 \pm \\
953.6\end{array}$ & $\begin{array}{l}4394.2 \pm \\
2033.9\end{array}$ & .4 & $\begin{array}{l}1383.2 \pm \\
1403.9\end{array}$ & $\begin{array}{l}534.8 \pm \\
471.3\end{array}$ & & .4 \\
\hline CD34 & $\begin{array}{l}12.8 \pm \\
5.7\end{array}$ & $\begin{array}{l}22.5 \pm \\
20.6\end{array}$ & .5 & $\begin{array}{l}45 \pm \\
20.8\end{array}$ & $\begin{array}{l}47.3 \pm \\
30.2\end{array}$ & .8 & $\begin{array}{l}10.8 \pm \\
2.1\end{array}$ & $\begin{array}{l}6.8 \pm \\
2.9\end{array}$ & & .8 \\
\hline CD45 & $\begin{array}{l}25.9 \pm \\
27.9\end{array}$ & $\begin{array}{l}14.5 \pm \\
7\end{array}$ & .8 & $\begin{array}{l}67.6 \pm \\
61.3\end{array}$ & $\begin{array}{l}43.7 \pm \\
24.7\end{array}$ & .6 & $\begin{array}{l}11.5 \pm \\
1.3\end{array}$ & $\begin{array}{l}6.9 \pm \\
2.7\end{array}$ & & .6 \\
\hline MHC I & $\begin{array}{l}346.2 \pm \\
59.2\end{array}$ & $\begin{array}{l}241.5 \pm \\
38.9\end{array}$ & .07 & $\begin{array}{l}217.9 \pm \\
69.1\end{array}$ & $\begin{array}{l}219.9 \pm \\
7.5\end{array}$ & .8 & $\begin{array}{l}44.9 \pm \\
6.9\end{array}$ & $\begin{array}{l}35.1 \pm \\
5.8\end{array}$ & & .8 \\
\hline MHC II & $\begin{array}{l}13.9 \pm \\
4.6\end{array}$ & $\begin{array}{l}22.8 \pm \\
19.8\end{array}$ & .4 & $\begin{array}{l}41.1 \pm \\
13.6\end{array}$ & $\begin{array}{l}46 \pm \\
27.5\end{array}$ & .6 & $\begin{array}{l}14.3 \pm \\
3.7\end{array}$ & $\begin{array}{l}8.5 \\
1.2\end{array}$ & & .6 \\
\hline
\end{tabular}

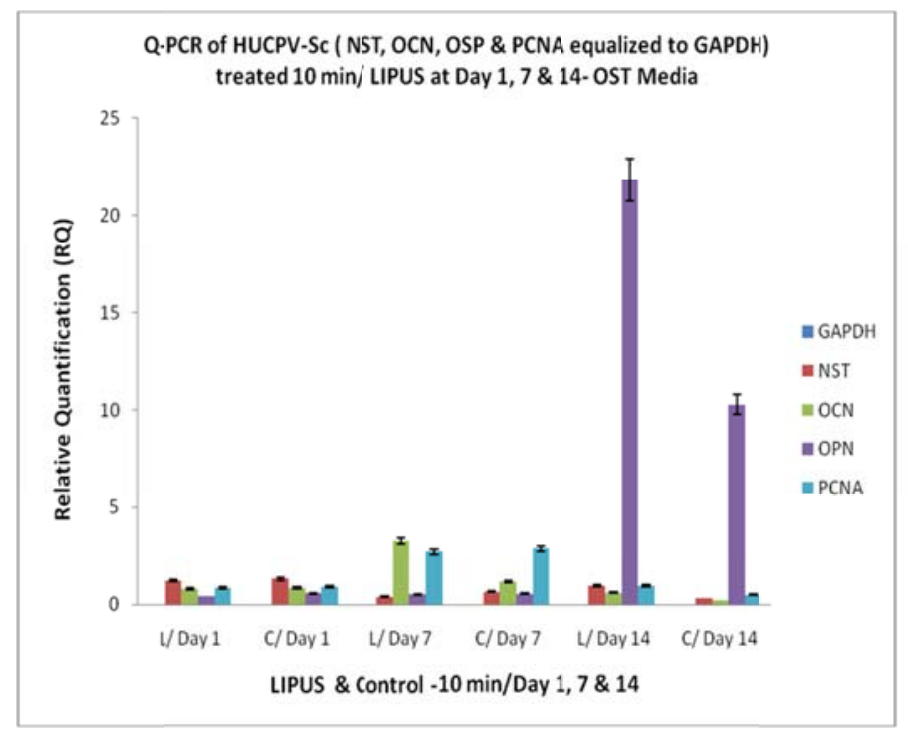

Figure 4. Q-PCR comparison of levels of nucleostemin, osteocalcin, osteopontin, and PCNA after their equalization to the endogenous control gene (GAPDH) between LIPUS (L) and control (C) on days 1, 7, and 14 in basic media. Cells were at $\mathrm{P} 4(\mathrm{n}=27)$, data represent quantification from 3 biological replicates, error has indicate standard deviation

The expressions of NST, PCNA, OCN and OPN were then investigated in LIPUS treated HUCPVCs (see Figure 4). The cells expressed a significantly higher level of OPN and PCNA in LIPUS-treated group $(P<.01)$ at day 14 (see Figure 4, 
Table 4). However, no difference in NST expression was observed at day 1, 7 or 14 . The level of OCN was almost 1.25 folds higher in the LIPUS treated group than the control at day 1 and 14, but was 1.25 folds less at day 7 .

Table 4. Q-PCR compare Mean \pm SD of Nucleostemin, Osteocalcin, Osteopontin and PCNA after their equalization to the endogenous control gene (GAPDH) between LIPUS (L) and control (C) at day 1, 7 and 14 in basic media

\begin{tabular}{|c|c|c|c|c|c|c|c|c|c|}
\hline \multirow{2}{*}{$\begin{array}{l}\text { Genes / } \\
\text { BM }\end{array}$} & \multicolumn{3}{|l|}{ Day 1} & \multicolumn{3}{|l|}{ Day 7} & \multicolumn{3}{|l|}{ Day 14} \\
\hline & $\mathbf{L}$ & C & $P$-Value & $\mathbf{L}$ & C & $P$-Value & $\mathbf{L}$ & C & $P$-Value \\
\hline GAPDH & $\begin{array}{l}.00 \pm \\
.00\end{array}$ & $\begin{array}{l}.00 \pm \\
.00\end{array}$ & .03 & $\begin{array}{l}.00 \pm \\
.00\end{array}$ & $\begin{array}{l}.00 \pm \\
.00\end{array}$ & .9 & $\begin{array}{l}.00 \pm \\
.00\end{array}$ & $\begin{array}{l}.00 \pm \\
.00\end{array}$ & .7 \\
\hline NST & $\begin{array}{l}1.58 \pm \\
.44\end{array}$ & $\begin{array}{l}1.33 \pm \\
.32\end{array}$ & .4 & $\begin{array}{l}.79 \pm \\
.03\end{array}$ & $\begin{array}{l}.81 \pm \\
.15\end{array}$ & .9 & $\begin{array}{l}.88 \pm \\
.16\end{array}$ & $\begin{array}{l}.85 \pm \\
.16\end{array}$ & .7 \\
\hline OCN & $\begin{array}{l}1.32 \pm \\
.27\end{array}$ & $\begin{array}{l}.82 \pm \\
.33\end{array}$ & .7 & $\begin{array}{l}.30 \pm \\
.04\end{array}$ & $\begin{array}{l}.43 \pm \\
.11\end{array}$ & .3 & $\begin{array}{l}1.26 \pm \\
.29\end{array}$ & $\begin{array}{l}.81 \pm \\
.22\end{array}$ & .9 \\
\hline OPN & $\begin{array}{l}1.18 \pm \\
.37\end{array}$ & $\begin{array}{l}.76 \pm \\
.21\end{array}$ & .9 & $\begin{array}{l}1.06 \pm \\
.12\end{array}$ & $\begin{array}{l}.99 \pm \\
.48\end{array}$ & .5 & $\begin{array}{l}7.95 \pm \\
6.20\end{array}$ & $\begin{array}{l}3.69 \pm \\
2.26\end{array}$ & .01 \\
\hline PCNA & $\begin{array}{l}1.38 \pm \\
.24\end{array}$ & $\begin{array}{l}.96 \pm \\
.28\end{array}$ & .9 & $\begin{array}{l}.33 \pm \\
.09\end{array}$ & $\begin{array}{l}.35 \pm \\
.17\end{array}$ & .5 & $\begin{array}{l}1.09 \pm \\
.49\end{array}$ & $\begin{array}{l}.61 \pm \\
.29\end{array}$ & .01 \\
\hline
\end{tabular}

\section{Discussion}

In this study, we investigated the effect of LIPUS on the characteristics and proliferation capacity of HUCPVCs. The 10 minutes LIPUS application was chosen based on previous study by Zhou et al., $2004{ }^{[31]}$ who reported that LIPUS showed its optimum stimulatory effect on skin fibroblasts when applied at 10 minutes per day for 7 days. Our results showed that LIPUS did not significantly increase HUCPVCs cell count after a 10 minute daily applications for days 1,7 , and 14 . This is in disagreement with previous studies that showed that LIPUS has a stimulatory effect on a variety of cell lines, such as osteoblasts, chondrocytes, and marrow-derived stromal cells ${ }^{[32-35]}$. This could be due to the possibility that HUCPVCs react differently to LIPUS compared to other cells.

The precise cellular mechanisms that mediate the observed therapeutic action of LIPUS are still not fully understood ${ }^{[36-38]}$. Yoon et al. $2009^{[21]}$ proposed that LIPUS stimulation will increase the capacity of human umbilical cord mesenchymal stem cells to proliferate by releasing extracellular matrix from Wharton's jelly and increasing the sensitivity of the cells to extracellular growth factors. However, it has been reported that cells from the Wharton's jelly behave differently from HUCPVCs ${ }^{[6]}$. It has been shown that the ultrasound transmitted energy invoke a direct effect on cell membrane permeability and on the second messenger adenylate cyclase activity in periosteal cells ${ }^{[26]}$. Subsequent changes in ion channels or protein transport, as a result of altered second messenger pathway could modify the intracellular signals for gene expression ${ }^{[26,27]}$. This may potentially be the same mechanisms that HUCPVCs respond to LIPUS as in our study, however that observation needs to be investigated further in future experiments. Alternatively, the use of low-intensity US reduces the heating of underlying tissues and also minimizes the extent of cavitation phenomena ${ }^{[29]}$. Wang et al. $1993{ }^{[29]}$ reported that application of mechanical stressors to the cytoskeleton could be reflected on cell metabolism with changes in gene expression. They also reported that modulating focal adhesion formation or changing extracellular matrix receptors number or location may alter cells sensitivity to a mechanical stimulus. In addition, Wang et al. 2004 also reported that nitric oxide was a major factor in mediating extracellular matrix released by LIPUS and induced osteoblasts to produce angiogenic factors after LIPUS application. Intermittent high-frequency acoustic pressure waves are a non-invasive form of mechanical stress using LIPUS protocol at frequencies ranging from $1.5-2 \mathrm{MHz}$ and intensity of $30 \mathrm{~mW} / \mathrm{cm}^{2}{ }^{[37]}$. 
Warden et al. $2001^{[39]}$ proposed that LIPUS increased the expression of c-fos and cyclooxygenase-2 genes and elevated mRNA levels for the bone matrix proteins alkaline phosphatase (ALP) and osteocalcin (OCN). In addition, Xing et al. $2012{ }^{[40]}$ reported that LIPUS increased cell permeability by induced monoclonal antibody production through structural changes in cellular outer membrane. The acoustic pressure of low frequency ultrasound waves does not increase the tissue temperature more than $1^{\circ} \mathrm{C}$ and does not significantly alter cellular activity ${ }^{[41]}$.

Conversely, other studies demonstrated that continuous mechanical stress may decrease the cellular activities as reflected on DNA content, ALP and calcium content ${ }^{[42]}$. The persistent mechanical stress may have reduced the activation of mechanosensitive cation channels in osteoblast-like cells ${ }^{[42]}$. Parvizi et al., $1999^{[43]}$ did not detect any effect of LIPUS on the expression of transforming growth factor- $\beta$, osteocalcin, alkaline phosphatase, and $\alpha$ (I)- procollagen genes in cultured osteoblasts. They noted that cell proliferation was not stimulated by ultrasound at 4, 6, 8 days at different intensities of 20 and $50 \mathrm{~mW} / \mathrm{cm}^{2}$. Their setting was however different from ours, or that of the clinically used LIPUS $\left(30 \mathrm{~mW} / \mathrm{cm}^{2}\right)$. Kinoshita et al. $2007^{[44]}$ reported that creating standing wave by direct contact of LIPUS transducer to the cultured cell in plate is one of the key elements in achieving successful sonoporation (ultrasound-induced cell membrane permeability) to establish a desired acoustic field.

Some of our study findings, notably the increased ALP at day 14 in the LIPUS group may be due to changes in cell membrane permeability by LIPUS. It has been reported that LIPUS cavitation results in changes in the permeability of cell membrane and calcium channels ${ }^{[43]}$. Those data suggest that the potential stimulatory effect of clinically applicable LIPUS treatment on these cells may occur at and beyond 14 days. Other recent studies on the effect of LIPUS on gingival and periodontal ligament cells showed similar results to ours that LIPUS at $30 \mathrm{~mW} / \mathrm{cm}^{2}$ for 5,10 and 20 minutes per day did not change ALP over 14 days ${ }^{[24,45]}$.

The lack of significant change in cell surface marker expression (as evaluated by the flowcytometry data in our experiment) may support, in part, our hypothesis that LIPUS maintains HUCPVC cell phenotypic characteristics after one day of treatment.

The significant increase of OPN mRNA by LIPUS compared to the sham group at day 14 as evaluated by Q-PCR is in agreement of previous study of the effect of LIPUS on gingival fibroblasts ${ }^{[24]}$ regardless the difference in LIPUS daily treatment time between our study and previous study ${ }^{[24]}$. This could be due to the difference in cell behavior and multipotency of HUCPVCs compared to gingival fibroblasts.

The significant increase in PCNA mRNA $(P<.01)$ by LIPUS compared to the sham control HUCPVCs without significant increase in cell number within the same period could be due to the fact that the increase in PCNA mRNA expression would take some time to have protein expression and consequent increase in cell proliferation. This rise in PCNA without a measurable increase in cell count in the LIPUS-treated, could also due to the short duration of LIPUS treatment in our study. This is supported by the findings of Yoon et al., $2009^{[21]}$ and may further validate some aspect of our hypothesis that LIPUS may increase PCNA (the proliferation gene of HUCPVCs) whilst maintaining their cell phenotypic characteristics after 14 days of treatment ${ }^{[21]}$. Experiments designed with a longer duration of LIPUS application may help further understanding of the biological behavior of HUCPVCs.

Although it has been hypothesized that LIPUS may increase blood flow around the fracture site during the application, this effect would extend for a period of time after removal of stimulus ${ }^{[46]}$. This may lead to maximizing the delivery of nutrients, metabolites, and growth factors. Also, Sena et al. $2005^{[47]}$ reported that LIPUS application resulted in elevated the expression of early response genes (c-jun, c-myc, Egr-1, cox-2) as well as bone differentiation marker genes osteonectin and osteopontin. The induction of those extracellular matrix genes represents the effect of LIPUS treatment.

The increased ALP, OPN, and OCN by LIPUS at day 14 were suggestive that LIPUS had an anabolic effect on HUCPVCs and may be helpful in the osteogenic differentiation of these cells. That finding was in agreement with previous reports that 
LIPUS enhanced ALP, OPN, OCN in different cell types ${ }^{[24,45]}$. The increased NST expression indicated that LIPUS stimulation maintained the cellular characteristics of HUCPV cells. That is in disagreement with another study which showed that LIPUS increased NST in gingival fibroblasts ${ }^{[48]}$. This again suggests that HUCPVCs are different from gingival fibroblasts regarding their multipotency. Several other studies support that the application of LIPUS on different type of cells may result in non-significant differences in cell proliferation ${ }^{[45-50]}$ and differentiation ${ }^{[24,37,49,54]}$. Our findings were consistent with the literature that studied mesenchymal stem cells ${ }^{[45,49,50,52]}$ and chondrocytes ${ }^{[43,48,49,50,53]}$, which postulated that the tissue mechanical stress induced by LIPUS may direct the cell efforts towards maintenance rather than proliferation and differentiation.

\section{Limitations of the study}

Application of LIPUS below tissue culture dish or plate may affect the actual LIPUS parameters that reaches treated cells in the tissue culture compared to applying LIPUS directly to the cells through culture medium ${ }^{[24,51,54]}{ }^{\text {. However, }}$ according to the report by Leskinen et al., $2012^{[25]}$, similar LIPUS frequency decreased about $7 \%$ when passes through culture plate. This in our opinion is negligible, however warrants further investigation.

\section{Conclusion}

The optimum application of LIPUS for HUCPVC expansion is yet to be determined. Our study concluded that LIPUS application for 10 minutes per day for 14 days induced the expression of OSP and PCNA without significant increase in cell proliferation of HUCPVCs. Further investigation is required to test the effect of prolonged LIPUS applications for more than 14 days on several variables, including the potential for HUCPVCs proliferation.

\section{Acknowledgment}

The authors thank the University of Alberta (McIntyre Fund for Dentistry, the University of Alberta) and Saudi Arabian Cultural Bureau for financial support and funding of this project.

\section{References}

[1] Liang J, Wu S, Zhao H, et al. Human umbilical cord mesenchymal stem cells derived from wharton's jelly differentiate into cholinergic-like neurons in vitro. Neurosci Lett. 2013 1/4; 532(0): 59-63.

[2] Han Y, Chai J, Sun T, et al. Differentiation of human umbilical cord mesenchymal stem cells into dermal fibroblasts in vitro. Biochem Biophys Res Commun. 2011 10/07; 413(4): 561-5.

[3] Kestendjieva S, Kyurkchiev D, Tsvetkova G, et al. Characterization of mesenchymal stem cells isolated from the human umbilical cord. Cell Biol. Int. 2008 Jul; 32(7): 724-32. PMid:18396423. http://dx.doi.org/10.1016/j.cellbi.2008.02.002

[4] Qiao C, Xu W, Zhu W, et al. Human mesenchymal stem cells isolated from the umbilical cord. Cell Biol. Int. 2008 Jan; 32 (1): 8-15. PMid:17904875. http://dx.doi.org/10.1016/j.cellbi.2007.08.002

[5] Sarugaser R, Lickorish D, Baksh D, et al. Human umbilical cord perivascular (HUCPV) cells: a source of mesenchymal progenitors. Stem Cells. 2005 Feb; 23(2): 220-9. PMid:15671145. http://dx.doi.org/10.1634/stemcells.2004-0166

[6] Subramanian A, Fong CY, Biswas A, et al. Comparative Characterization of Cells from the Various Compartments of the Human Umbilical Cord Shows that the Wharton's Jelly Compartment Provides the Best Source of Clinically Utilizable Mesenchymal Stem Cells. PLoS One. 2015 Jun 10; 10(6): e0127992. PMid:26061052. http://dx.doi.org/10.1371/journal.pone.0127992

[7] Baksh D, Yao R, Tuan RS. Comparison of proliferative and multilineage differentiation potential of human mesenchymal stem cells derived from umbilical cord and bone marrow. Stem Cells. 2007 Jun; 25(6): 1384-92. PMid:17332507. http://dx.doi.org/10.1634/stemcells.2006-0709

[8] Hofmeister CC, Zhang J, Knight KL, et al. Ex vivo expansion of umbilical cord blood stem cells for transplantation: growing knowledge from the hematopoietic niche. Bone Marrow Transplant. 2007 Jan; 39(1): 11-23. PMid:17164824.

http://dx.doi.org/10.1038/sj.bmt.1705538 
[9] Park KS, Lee YS, Kang KS. In vitro neuronal and osteogenic differentiation of mesenchymal stem cells from human umbilical cord blood. J. vet. sci. 2006 Dec; 7(4): 343-8. PMid:17106225. http://dx.doi.org/10.4142/jvs.2006.7.4.343

[10] Bieback K, Kern S, Kluter H, et al. Critical parameters for the isolation of mesenchymal stem cells from umbilical cord blood. Stem Cells. 2004; 22(4): 625-34. PMid:15277708. http://dx.doi.org/10.1634/stemcells.22-4-625

[11] Miao Z, Jin J, Chen L, et al. Isolation of mesenchymal stem cells from human placenta: comparison with human bone marrow mesenchymal stem cells. Cell Biol. Int. 2006 Sep; 30(9): 681-7. PMid:16870478. http://dx.doi.org/10.1016/j.cellbi.2006.03.009

[12] Yen BL, Huang HI, Chien CC, et al. Isolation of multipotent cells from human term placenta. Stem Cells. 2005; 23(1): 3-9. PMid:15625118. http://dx.doi.org/10.1634/stemcells.2004-0098

[13] Kim J, Lee Y, Kim H, et al. Human amniotic fluid-derived stem cells have characteristics of multipotent stem cells. Cell Prolif. 2007 Feb; 40(1): 75-90. PMid:17227297. http://dx.doi.org/10.1111/j.1365-2184.2007.00414.x

[14] Gang EJ, Hong SH, Jeong JA, et al. In vitro mesengenic potential of human umbilical cord blood-derived mesenchymal stem cells. Biochem. Biophys. Res. Commun. 2004 Aug 13; 321(1): 102-8. PMid:15358221. http://dx.doi.org/10.1016/j.bbrc.2004.06.111

[15] Musina RA, Bekchanova ES, Sukhikh GT. Comparison of mesenchymal stem cells obtained from different human tissues. Bull. Exp. Biol. Med. 2005 Apr; 139(4): 504-9. PMid:16027890. http://dx.doi.org/10.1007/s10517-005-0331-1

[16] Rosada C, Justesen J, Melsvik D, et al. The human umbilical cord blood: a potential source for osteoblast progenitor cells. Calcif. Tissue Int. 2003 Feb; 72(2): 135-42. PMid:12457262. http://dx.doi.org/10.1007/s00223-002-2002-9

[17] Wagner W, Wein F, Seckinger A, et al. Comparative characteristics of mesenchymal stem cells from human bone marrow, adipose tissue, and umbilical cord blood. Exp. Hematol. 2005 Nov; 33(11): 1402-16. PMid:16263424. http://dx.doi.org/10.1016/j.exphem.2005.07.003

[18] Zhang Y, Li C, Jiang X, et al. Human placenta-derived mesenchymal progenitor cells support culture expansion of long-term culture-initiating cells from cord blood CD34+ cells. Exp. Hematol. 2004 Jul; 32(7):657-64. PMid:15246162. http://dx.doi.org/10.1016/j.exphem.2004.04.001

[19] Duarte LR. The stimulation of bone growth by ultrasound. Arch. Orthop. Trauma. Surg. 1983; 101(3): 153-9. PMid:6870502. http://dx.doi.org/10.1007/BF00436764

[20] Childs SG. Stimulators of bone healing. Biologic and biomechanical. Orthopaedic Nursing. 2003 Nov-Dec; 22(6): 421-8. PMid:14705472. http://dx.doi.org/10.1097/00006416-200311000-00010

[21] Yoon JH, Roh EY, Shin S, et al. Introducing pulsed low-intensity ultrasound to culturing human umbilical cord-derived mesenchymal stem cells. Biotechnol. Lett. 2009 Mar; 31(3): 329-35. PMid:18985278. http://dx.doi.org/10.1007/s10529-008-9872-5

[22] Marvel S, Okrasinski S, Bernacki SH, et al. The development and validation of a LIPUS system with preliminary observations of ultrasonic effects on human adult stem cells. IEEE Trans Ultrason Ferroelectr Freq Control. 2010 Sep; 57(9): 1977-84. PMid:20875987. http://dx.doi.org/10.1109/TUFFC.2010.1645

[23] Li L, Wu S, Liu Z, et al. Ultrasound-Targeted Microbubble Destruction Improves the Migration and Homing of Mesenchymal Stem Cells after Myocardial Infarction by Upregulating SDF-1/CXCR4: A Pilot Study. Stem Cells Int. 2015; $2015: 691310$.

[24] Mostafa NZ, Uludag H, Dederich DN, et al. Anabolic Effects of Low Intensity Pulsed Ultrasound on Gingival Fibroblasts. Archives of Oral Biology. 2009; 54 (8): 743-8.

[25] Leskinen JJ, Hynynen K. Study of factors affecting the magnitude and nature of ultrasound exposure with in vitro set-ups. Ultrasound Med Biol. 2012 May; 38(5): 777-94. PMid:22425382. http://dx.doi.org/10.1016/j.ultrasmedbio.2012.01.019

[26] Leung KS, Cheung WH, Zhang C, et al. Low intensity pulsed ultrasound stimulates osteogenic activity of human periosteal cells. Clin. Orthop. 2004 Jan (418): 253-259. PMid:15043127. http://dx.doi.org/10.1097/00003086-200401000-00044

[27] Martini L, Giavaresi G, Fini M, et al. Effect of extracorporeal shock wave therapy on osteoblastlike cells. Clin. Orthop. 2003 Aug; (413): 269-280. PMid:12897619. http://dx.doi.org/10.1097/01.blo.0000073344.50837.cd

[28] Webster DF, Harvey W, Dyson M, et al. The role of ultrasound-induced cavitation in the 'in vitro' stimulation of collagen synthesis in human fibroblasts. Ultrasonics. 1980 Jan; 18(1): 33-37. http://dx.doi.org/10.1016/0041-624X(80)90050-5

[29] Wang N, Butler JP, Ingber DE. Mechanotransduction across the cell surface and through the cytoskeleton. Science. 1993 May 21; 260(5111): 1124-7. PMid:7684161. http://dx.doi.org/10.1126/science.7684161

[30] Doan N, Reher P, Meghji S, et al. In vitro effects of therapeutic ultrasound on cell proliferation, protein synthesis, and cytokine production by human fibroblasts, osteoblasts, and monocytes. J. Oral Maxillofac. Surg. 1999 discussion 420; Apr; 57(4): 409-19.

[31] Zhou S, Schmelz A, Seufferlein T, et al. Molecular mechanisms of low intensity pulsed ultrasound in human skin fibroblasts. J. Biol. Chem. 2004 Dec 24; 279(52): 54463-9. PMid:15485877. http://dx.doi.org/10.1074/jbc.M404786200 
[32] Naruse K, Mikuni-Takagaki Y, Azuma Y, et al. Anabolic response of mouse bone-marrow-derived stromal cell clone ST2 cells to low-intensity pulsed ultrasound. Biochem. Biophys. Res. Commun. 2000 Feb 5; 268(1): 216-20. PMid:10652238. http://dx.doi.org/10.1006/bbrc.2000.2094

[33] Sun JS, Hong RC, Chang WH, et al. In vitro effects of low-intensity ultrasound stimulation on the bone cells. J. Biomed. Mater. Res. 2001 Dec 5; 57(3): 449-56. http://dx.doi.org/10.1002/1097-4636(20011205)57:3<449::AID-JBM1188>3.0.CO;2-0

[34] Zhang ZJ, Huckle J, Francomano CA, et al. The effects of pulsed low-intensity ultrasound on chondrocyte viability, proliferation, gene expression and matrix production. Ultrasound Med. Biol. 2003 Nov; 29(11): 1645-51. PMid:14654159. http://dx.doi.org/10.1016/j.ultrasmedbio.2003.08.011

[35] Winter LC, Walboomers XF, Bumgardner JD, et al. Intermittent versus continuous stretching effects on osteoblast-like cells in vitro. J. Biomed. Mater. Res. A. 2003 Dec 15; 67(4): 1269-75. PMid:14624513. http://dx.doi.org/10.1002/jbm.a.20028

[36] Min BH, Woo JI, Cho HS, et al. Effects of low-intensity ultrasound (LIUS) stimulation on human cartilage explants. Scand. J. Rheumatol. 2006 Jul-Aug; 35(4): 305-11. PMid:16882596. http://dx.doi.org/10.1080/03009740600588418

[37] Wang FS, Kuo YR, Wang CJ, et al. Nitric oxide mediates ultrasound-induced hypoxia-inducible factor-1alpha activation and vascular endothelial growth factor-A expression in human osteoblasts. Bone. 2004; 35 (1): 114-23. PMid:15207747. http://dx.doi.org/10.1016/j.bone.2004.02.012

[38] Qin L, Fok P, Lu H, et al. Low intensity pulsed ultrasound increases the matrix hardness of the healing tissues at bone-tendon insertion - A partial patellectomy model in rabbits. Clin.Biomech. 2006; 21(4): 387-94. PMid:16427166. http://dx.doi.org/10.1016/j.clinbiomech.2005.11.008

[39] Warden S, Favaloro J, Bennell K, et al. Low-intensity pulsed ultrasound stimulates a bone-forming response in UMR-106 cells. Biochemical and Biophysical Research. 2001 Aug 24; 286(3): 443-50. PMid:11511078. http://dx.doi.org/10.1006/bbrc.2001.5412

[40] Xing J, Yang X, Xu P, et al. Original Contribution: Ultrasound-Enhanced Monoclonal Antibody Production. Ultrasound in Medicine \& Biology. 2012 Nov; 38: 1949-57. PMid:22939294. http://dx.doi.org/10.1016/j.ultrasmedbio.2012.06.008

[41] Chang WHS, Sun JS, Chang SP, et al. Study of thermal effects of ultrasound stimulation on fracture healing. Bioelectromagnetics. 2002; 23: 256-63. PMid:11948604. http://dx.doi.org/10.1002/bem.10009

[42] Duncan RL, Hruska KA. Chronic, intermittent loading alters mechanosensitive channel characteristics in osteoblast-like cells. Am. J. Physiol. 1994 Dec; 267(6 Pt 2): F909-16. PMid:7528987.

[43] Parvizi J, Wu CC, Lewallen DG, et al. Low-intensity ultrasound stimulates proteoglycan synthesis in rat chondrocytes by increasing aggrecan gene expression. J. Orthop. Res. 1999 Jul; 17(4): 488-94. PMid:10459753. http://dx.doi.org/10.1002/jor.1100170405

[44] Kinoshita M1, Hynynen K. Key factors that affect sonoporation efficiency in in vitro settings: the importance of standing wave in sonoporation. Biochem Biophys Res Commun. 2007 Aug 10; 359(4): 860-5. PMid:17568561. http://dx.doi.org/10.1016/j.bbrc.2007.05.153

[45] Hu B, Zhang Y, Zhou J, et al. Low-intensity pulsed ultrasound stimulation facilitates osteogenic differentiation of human periodontal ligament cells. PLoS One. 2014 Apr 17; 9(4): e95168. PMid:24743551. http://dx.doi.org/10.1371/journal.pone.0095168

[46] Rawool N, Goldberg B, Forsberg F, et al. Power Doppler assessment of vascular changes during fracture treatment with low-intensity ultrasound. Journal of Ultrasound in Medicine. 2003 Feb; 22(2): 145-53. PMid:12562119.

[47] Sena K, Leven R, Mazhar K, et al. Early gene response to low-intensity pulsed ultrasound in rat osteoblastic cells. Ultrasound in Medicine \& Biology. 2005 May; 31(5): 703-8. PMid:15866420. http://dx.doi.org/10.1016/j.ultrasmedbio.2005.01.013

[48] El-Bialy T, Alhadlaq A, Wong B, et al. Ultrasound effect on neural differentiation of gingival stem/progenitor cells. Ann Biomed. Eng. 2014 Jul; 42(7): 1406-12. PMid:24752635. http://dx.doi.org/10.1007/s10439-014-1013-9

[49] Ebisawa K, Hata K, Okada K, et al. Ultrasound enhances transforming growth factor beta-mediated chondrocyte differentiation of human mesenchymal stem cells. Tissue Eng. 2004 May-Jun; 10(5-6): 921-9. PMid:15265310. http://dx.doi.org/10.1089/1076327041348437

[50] Schumann D, Kujat R, Zellner J, et al. Treatment of human mesenchymal stem cells with pulsed low intensity ultrasound enhances the chondrogenic phenotype in vitro. Biorheology. 2006; 43(3-4): 431-43. PMid:16912415.

[51] Toyoda T, Seedhom BB, Kirkham J, et al. Upregulation of aggrecan and type II collagen mRNA expression in bovine chondrocytes by the application of hydrostatic pressure. Biorheology. 2003; 40(1-3): 79-85. PMid:12454390.

[52] Malley A, Stewart CC, Stewart SJ, et al. Flow cytometric analysis of I-J expression on murine bone marrow-derived macrophages. J.Leukoc.Biol. 1988 Jun; 43(6): 557-65. PMid:2454280. 
[53] Angele P, Schumann D, Angele M, et al. Cyclic, mechanical compression enhances chondrogenesis of mesenchymal progenitor cells in tissue engineering scaffolds. Biorheology. 2004; 41(3-4): 335-46. PMid:15299266.

[54] Inubushi T, Tanaka E, Rego EB, et al. Effects of ultrasound on the proliferation and differentiation of cementoblast lineage cells. J. Periodontol. 2008 Oct; 79(10): 1984-90. PMid:18834255. http://dx.doi.org/10.1902/jop.2008.080081

[55] Korstjens CM, Nolte PA, Burger EH, et al. Stimulation of bone cell differentiation by low-intensity ultrasound-a histomorphometric in vitro study. J. Orthop. Res. 2004 May; 22(3):495-500. PMid:15099626. http://dx.doi.org/10.1016/j.orthres.2003.09.011 